\title{
Role of supratidal invertebrates in the decomposition of beach-cast green algae UIva sp.
}

\author{
Alessandro Catenazzi ${ }^{1, *}$, Maureen A. Donnelly \\ Florida International University, Department of Biological Sciences, Miami, Florida 33199, USA \\ ${ }^{1}$ Present address: Division of Integrative Biology, University of South Florida, Tampa, Florida 33620, USA
}

\begin{abstract}
We examined the effects of supratidal invertebrates on the decomposition of the green alga Ulva sp. in Paracas Bay, southern Peru. The species identification of Ulva sp. was problematic; thus, we decided to refer to the broadbladed Ulva occuring in Paracas Bay by the generic name. We used stable isotopes of carbon and nitrogen to evaluate the flow of energy and nutrients from the decomposing algae to the community of supratidal consumers. We found that supratidal invertebrates had little effect on the decomposition rate of beach-cast macroalgae. Algae lost $46.5 \%$ of their initial weight within $18 \mathrm{~d}$ from initial stranding ashore. The most abundant arthropods in samples of $100 \mathrm{~g}$ wet Ulva sp. packs were the springtail Paraxenylla peruensis (1165.9 ind. pack ${ }^{-1}$ ), a sphaerocerid fly (23.6 adults pack ${ }^{-1}$ ) and at least 3 species of mites $\left(82.9\right.$ ind. pack $\left.^{-1}\right)$. In terms of biomass, the main consumers were the talitrid amphipod Transorchestia chiliensis $\left(42.8 \mathrm{mg} \mathrm{pack}^{-1}\right)$, P. peruensis $\left(2.8 \mathrm{mg} \mathrm{pack}{ }^{-1}\right)$ and mites $\left(1.3 \mathrm{mg} \mathrm{pack}^{-1}\right)$. Carbon isotopic values suggested that Ulva sp. was the most important source of energy to arthropod consumers, whereas nitrogen isotopic values indicated that mites and centipedes occupy high trophic positions in the supratidal food web. Paracas Bay abuts a hyper-arid desert wherein vegetation is extremely scarce and patchy. Supratidal invertebrates feeding upon decomposing Ulva sp., despite having little direct effect on the rate of Ulva sp. decomposition, establish a critical link between the marine and terrestrial ecosystems because they make marine-derived energy and nutrients available to desert consumers.
\end{abstract}

KEY WORDS: Marine macrophyte - Breakdown - Invertebrate shredders $\cdot$ Carbon and nitrogen stable isotopes $\cdot$ Allochthonous input $\cdot$ Peru $\cdot$ Coastal desert

\section{INTRODUCTION}

Decomposition is a key ecosystem process because it converts nutrients from organic to inorganic forms and makes these nutrients available to primary producers and consumers (Chapin et al. 2002). Decomposing mats of beach-cast macroalgae are important sources of carbon and nutrients for subtidal and intertidal organisms (Bedford \& Moore 1984, Bolam et al. 2000). However, few studies have examined the importance of decomposing macroalgae as sources of energy and nutrients for supratidal communities, except for sandy beach ecosystems (Griffiths et al. 1983, Koop \& Lucas 1983). The recent focus on terrestrial habitats linked to marine productivity through the movement of nutrients, prey and predators led to numerous investigations, some of which emphasized the importance of beach-cast macrophytes as a source of allochthonous material for terrestrial producers and consumers (e.g. Bustamante \& Branch 1996).

The ecological role of invertebrate shredders has proved difficult to evaluate in the field, with some studies claiming that grazers remove up to 60 to $80 \%$ of organic algal input (Griffiths \& Stenton-Dozey 1981) and other studies reporting no significant effects of macrofauna on the decomposition rate of beach-cast seaweeds (Inglis 1989, Jedrzejczak 2002). During decomposition, several abiotic and biotic processes cause a decrease in detrital mass and the release of nutrients and $\mathrm{CO}_{2}$ from decaying organic matter. It is often assumed that invertebrates are directly involved in the decomposition of organic matter; however, little is known about the feeding patterns and trophic relationships of invertebrate species living in decomposing 
organic matter. Mites, for example, form a large group of soil invertebrates that includes detritivorous, omnivorous, predaceous and parasitic forms. Beach-cast macrophytes may not be the only source of energy for supratidal consumers found in decomposing mats. Autotrophic organisms, such as diatoms, growing on the surface of decomposing particles may provide additional sources of food for algivores or detritivores.

The goal of this study was to evaluate the role of supratidal invertebrates in the decomposition rate of green algae of the genus Ulva on a shelly beach in central Peru. Ulva sp. is a conspicuous component of marine wrack that washes ashore in small- to mediumsized bays along the Peruvian coast (Koepcke \& Koepcke 1952). We performed a 'litter bag' experiment, enclosing samples of algae of known mass in bags having different mesh sizes to control the colonization of Ulva sp. by species of supratidal invertebrates, and measured the rate of mass loss in algal samples during a $3 \mathrm{wk}$ period. We hypothesized that the presence of large arthropods would accelerate the decomposition of algal samples. In addition, we used $\delta^{13} \mathrm{C}$ to determine whether Ulva sp. was a significant source of carbon to supratidal invertebrates and $\delta^{15} \mathrm{~N}$ to infer the trophic position of supratidal invertebrates associated with decomposing algae.

\section{MATERIALS AND METHODS}

Study site. We conducted our study on a shelly beach of Paracas Bay, Peru $\left(13^{\circ} 51^{\prime} \mathrm{S}, 76^{\circ} 16^{\prime} \mathrm{W}\right)$ between 8 May and 8 June 2003. This beach is narrow $(<20 \mathrm{~m}$ wide) and has a semi-diurnal tidal cycle (average tidal range, $0.58 \mathrm{~m})$. Waters enclosed within Paracas Bay $(\sim 15 \times 7 \mathrm{~km})$ are calm because they are protected from winds and marine currents by a peninsula. Paracas lies close to one of the strongest upwelling centers along the Peruvian coast (Catenazzi \& Donnelly 2007). The species identification of Ulva sp. was problematic; thus, we decided to refer to the broad-bladed Ulva sp. occurring in Paracas Bay by the generic name. The high oceanic productivity, along with shallow waters and the possible influence of industrial effluents from fishmeal processing facilities, favors the overgrowth of Ulva sp. in the bay. Drift input of other macroalgae was negligible compared with that of Ulva sp. throughout 2003 (Catenazzi \& Donnelly 2007).

The beaches of Paracas Bay are bordered by one of the driest deserts on Earth $(<2 \mathrm{~mm}$ annual rainfall). Temperatures are mild and range between an average of $22.9^{\circ} \mathrm{C}$ in February to $16.3^{\circ} \mathrm{C}$ in August. The desert is devoid of vegetation except for the halophyte Sesuvium portulacastrum that colonizes small supralittoral dunes. We worked along a sheltered beach composed of empty shells, pebbles and decaying algal material. The shells originated from the erosion of a quaternary deposit located 10 to $20 \mathrm{~cm}$ beneath the ground. The subtidal zone along this segment was mainly composed of mud mixed with pebbles alternated with zones of rocky substrate.

Litter bags. We used litter bags with $5 \mathrm{~mm}, 1 \mathrm{~mm}$ or $80 \mu \mathrm{m}$ mesh size to evaluate the role of different components of the supratidal invertebrate community during algal decomposition. These bags contained packs of $100 \mathrm{~g}$ portions of blotted dry thalli of Ulva sp. We performed 2 experiments for an original duration of $18 \mathrm{~d}$. During the first experiment, bags were lost during a spring tide, limiting our data set to the first $9 \mathrm{~d}$ ( 8 to 16 May 2003). During the second experiment, all bags were recovered at the end of the $18 \mathrm{~d}$ period (22 May to 8 June 2003). Bags were collected at 1, 3, 9 and $18 \mathrm{~d}$ after initial placement on the beach.

We collected fresh samples of Ulva sp. floating near shore. In the laboratory, we rinsed algal samples to remove invertebrates and small bits of detritus. We prepared experimental litter bags $25 \times 20 \mathrm{~cm}$ in size. We weighed $100 \mathrm{~g}$ portions of blotted dry thalli of Ulva sp. and enclosed them in separate bags of each of the 3 mesh sizes. We dried and weighed to constant mass ten $100 \mathrm{~g}$ portions of blotted dry Ulva sp. to estimate the initial dry weight value. Mesh size treatments were assigned randomly to Ulva sp. portions. We prepared 4 (Trial 1) and 5 (Trial 2) bags for each mesh size and sampling day, for a total of 36 (Trial 1) and 60 bags (Trial 2).

Bags were randomly positioned in 4 (Trial 1) or 5 sites (Trial 2). We placed a series of 3 bags of different mesh sizes at each site (distance between sites was $\sim 100 \mathrm{~m}$ ) during low tide at night in areas immediately above the mean high tide line. Most of the algal material washed ashore in Paracas Bay is periodically floated and deposited between successive tidal periods. All bags were covered with similar amounts of previously cleaned Ulva sp. to protect packs from desiccation.

After being recovered from the field, Ulva sp. packs were taken to the lab in sealed plastic bags. We processed bag contents through a $20 \mu \mathrm{m}$ mesh sieve and transferred the contents to vials containing $70 \%$ ethanol. Invertebrates were sorted into taxonomic groups, identified to species level when possible and individually counted under a stereoscope. Unidentified species represented a negligible proportion of the overall number and biomass of invertebrates (Table 1). Ulva sp. thalli were removed from bags and individually cleaned to recover invertebrates that had remained attached to the algae. Cleaned Ulva sp. thalli were dried at $60^{\circ} \mathrm{C}$ and weighed until they reached constant mass. Invertebrate biomass was estimated by means of body-length-dry-mass relationships based 
Table 1. Ulva sp.. Initial pack mass $\left(m_{0}\right)$ and breakdown coefficients $(k)$ of thalli in Paracas Bay, Peru, estimated by nonlinear regression analysis for bags with mesh sizes of $5 \mathrm{~mm}, 1 \mathrm{~mm}$ and $80 \mu \mathrm{m} . \mathrm{n}=$ number of bags containing packs of $100 \mathrm{~g}$ blotted dry Ulva sp. ${ }^{* * *} \mathrm{p}<0.001,{ }^{*} \mathrm{p}<0.05$

\begin{tabular}{|crlll|}
\hline Mesh size & $m_{0} \pm \mathrm{SE}(\%)$ & $k \pm \mathrm{SE}\left(\mathrm{d}^{-1}\right)$ & $\mathrm{r}^{2}$ & $\mathrm{n}$ \\
\hline Trial 1 & & & & \\
$5 \mathrm{~mm}$ & $107.9 \pm 5.8$ & $0.062 \pm 0.013$ & $0.743^{* * *}$ & 12 \\
$1 \mathrm{~mm}$ & $85.4 \pm 5.6$ & $0.041 \pm 0.014$ & $0.482^{*}$ & 12 \\
$80 \mu \mathrm{m}$ & $108.0 \pm 7.1$ & $0.042 \pm 0.014$ & $0.494^{*}$ & 12 \\
Trial 2 & & & & \\
$5 \mathrm{~mm}$ & $75.6 \pm 3.1$ & $0.022 \pm 0.005$ & $0.561^{* * *}$ & 20 \\
$1 \mathrm{~mm}$ & $85.5 \pm 2.7$ & $0.031 \pm 0.004$ & $0.793^{* * *}$ & 20 \\
$80 \mu \mathrm{m}$ & $79.5 \pm 3.6$ & $0.020 \pm 0.005$ & $0.475^{* * *}$ & 20 \\
\hline
\end{tabular}

iterative $(\mathrm{n}=100)$ fitting procedures. Initial assumed values (i.e. $m=100 \mathrm{~g}$ at Day 0) were excluded from the model. The model assumes that the mass loss at any given time is directly proportional to the algal mass present (Hieber \& Gessner 2002).

We used a repeated measures ANOVA to examine the effect of litterbag mesh size on the decomposition rate of Ulva sp. after 1, 2 and $9 \mathrm{~d}$ for Trial 1 and after 1, 3, 9 and $18 \mathrm{~d}$ for Trial 2. We compared weight loss patterns between the 2 trials and for each mesh size with analyses of covariance

on specimens collected at the field site. We used the average dry mass of 10 to 20 individuals for small invertebrates.

Stable isotope analyses. We used invertebrates collected from Ulva sp. packs in $5 \mathrm{~mm}$ mesh bags to explore natural variation in $\delta^{13} \mathrm{C}$ and $\delta^{15} \mathrm{~N}$. In addition to these invertebrates, we collected centipedes Thindyla litoralis and solifuges Chinchippus peruvianus that live in the intertidal zone where we conducted our experiment (Catenazzi \& Donnelly 2007). We used carbon isotopic ratios to evaluate the source of carbon, whereas $\delta^{15} \mathrm{~N}$ was used to infer trophic position for the most conspicuous consumers (based on biomass data).

All samples were oven dried at $60^{\circ} \mathrm{C}$ for $48 \mathrm{~h}$, ground with mortar and pestle and defatted with a dichloromethane:methanol (9:1) solution before stable isotope analysis. Isotopic analyses were conducted on a Finnigan MAT Delta Plus continuous flow isotope ratio mass spectrometer. We analyzed 3 to $4 \mathrm{mg}$ of algal samples and $\sim 0.4$ to $0.7 \mathrm{mg}$ of animal samples. Homogenized samples of consumers included 1 individual for large predators (rove beetle, solifuge, centipede), 5 to 6 individuals of the rove beetle Carpelimus sp., 10 to 15 individual flies, 50 to 60 individual mites and 400 to 450 individual springtails. We analyzed 5 replicates for each consumer. Values of $\delta^{13} \mathrm{C}$ and $\delta^{15} \mathrm{~N}$ are expressed relative to their respective international standards, Pee Dee belemnite and atmospheric air. We analyzed $16 \%$ of our samples in duplicate and calculated the average standard deviation (SD) on duplicated data to determine accuracy of our data. The average SD for replicate samples was $0.11 \%$ or for $\delta^{13} \mathrm{C}$ and $0.13 \%$ for $\delta^{15} \mathrm{~N}$.

Statistical analyses. Data on algal mass loss during breakdown were fitted to the exponential model:

$$
m_{t}=m_{0} e^{-k t}
$$

where $m_{0}$ is the initial dry mass of algal packs, $m_{t}$ is the remaining dry mass at time $t$ and $k$ is a breakdown rate coefficient, the daily rate of mass loss. The parameters of the model were calculated using nonlinear
(ANCOVAs) on log-transformed data. We compared the full model (different slope and intercept between the 2 trials) with 2 reduced models ('same slope, different intercept' and 'same slope and intercept') by using a General Linear Test (GLT). The GLT tests the null hypothesis that the regression coefficients for all additional variables are equal to zero. Temporal succession in the number and biomass of invertebrates was compared using ANOVAs for data from $5 \mathrm{~mm}$ bags only. Data from $1 \mathrm{~mm}$ and $80 \mu \mathrm{m}$ bags were not used because these bags contained subsets of the supratidal invertebrate fauna that were not representative of decomposition under natural conditions (i.e. they excluded invertebrates larger than $80 \mu \mathrm{m}$ or $1 \mathrm{~mm}$ ). We used a 2-way ANOVA with $d$ and mesh size as factors to evaluate differences in abundance and biomass of invertebrates in $5 \mathrm{~mm}$ and $1 \mathrm{~mm}$ bags ( $80 \mu \mathrm{m}$ bags were not used because some had many invertebrates larger than $80 \mu \mathrm{m})$. Measurements of decomposition rates and number and biomass (on $\log (x+1)$-transformed data) of invertebrates were tested for normality and homogeneity of variance before parametric tests were conducted. We ran all our statistical analyses in R (www.r-project.org). Data are reported as means $\pm \mathrm{SE}$ and differences were considered significant when $\mathrm{p}<0.05$.

We used stable isotope data to examine whether Ulva sp. was the main source of carbon for arthropods found in the litterbags and to estimate the trophic position of the main consumers. We addressed the first question by contrasting the $\delta^{13} \mathrm{C}$ of consumers with the $\delta^{13} \mathrm{C}$ of Ulva sp. with a Student's $t$-test. The values for consumers were corrected for different trophic fractionations by assuming an average trophic fractionation of $0.39 \%$ (Post 2002). We used $\delta^{15} \mathrm{~N}$ values to estimate the trophic position of consumers. We assumed that Ulva sp. was the basal resource for all invertebrates found in litterbags. Trophic position was estimated by using the formula (Post 2002):

$$
\text { trophic position }=\lambda+\left(\delta^{15} \mathrm{~N}_{\text {consumer }}-\delta^{15} \mathrm{~N}_{\text {Ulva }}\right) / \Delta_{\mathrm{n}}
$$


where $\lambda=1$ is the trophic position of Ulva sp. and $\Delta_{\mathrm{n}}$ is the estimated trophic fractionation, assuming a mean fractionation of 3.4\% for each trophic level (Post 2002). We used average values (without SDs) of $\delta^{15} \mathrm{~N}_{\text {Ulva }}$ to simplify calculations.

\section{RESULTS}

\section{Ulva sp. decomposition}

Algal packs underwent substantial breakdown during the experimental period (Fig. 1). Breakdown coefficients varied between 0.020 and $0.062 \mathrm{~d}^{-1}$ (Table 1). The loss of initial weight was $37.54 \pm 2.27 \%(\mathrm{n}=27)$ within $9 \mathrm{~d}$ for both trials combined and $46.51 \pm 1.92 \%$ ( $\mathrm{n}=15$ ) within $18 \mathrm{~d}$ in Trial 2. However, the exponen-

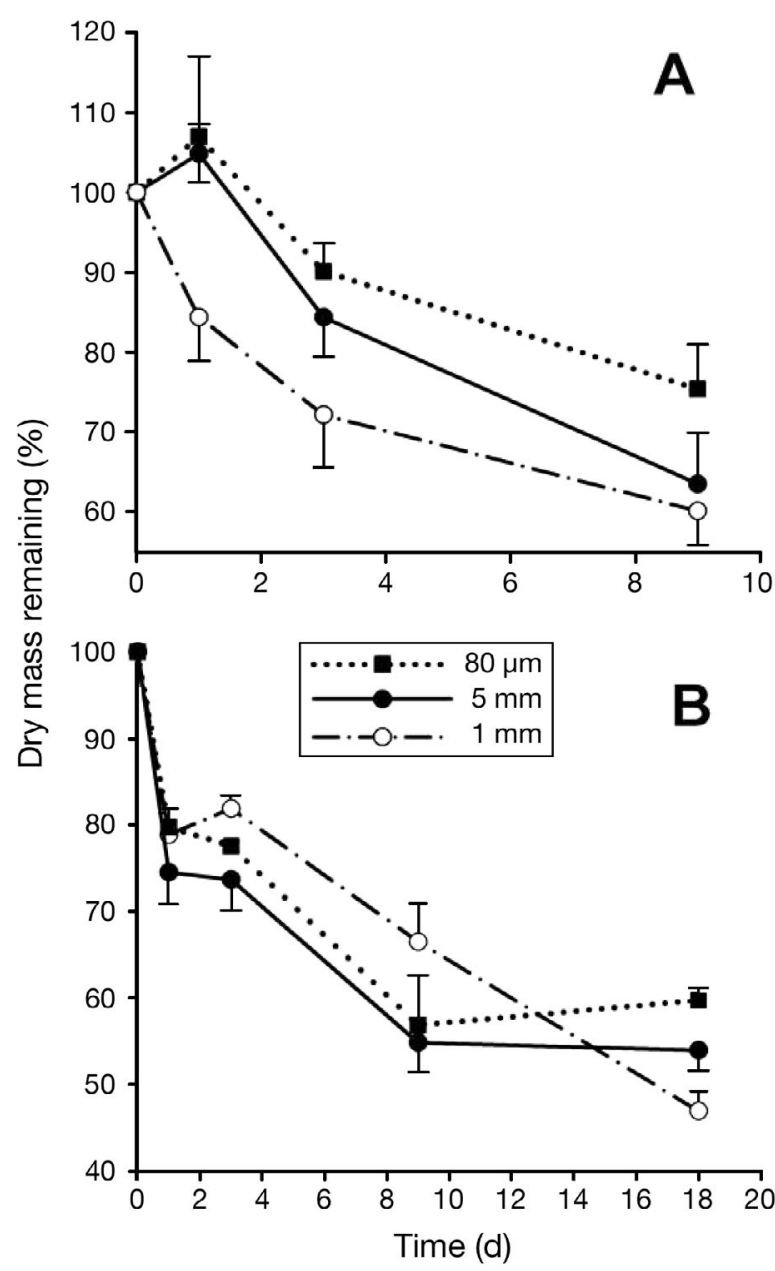

Fig. 1. Ulva sp. Dry mass remaining in bags with $80 \mu \mathrm{m}(\mathbf{\square})$, $1 \mathrm{~mm}(\mathrm{O})$ and $5 \mathrm{~mm}(\bullet)$ mesh decomposing on a shelly beach in Paracas Bay during (A) Trial 1 (8 May to 16 May 2003) and

(B) Trial 2 (22 May to 8 June 2003). Error bars indicate SE calculated from 4 (Trial 1) and 5 (Trial 2) replicate bags tial breakdown model explained only 47 to $79 \%$ of the variation in decomposition rates of Ulva sp.

Patterns of weight loss were similar across bags of different mesh sizes and between the 2 trials (at least up to Day 9; Table 2). When any difference was found, a reduced model testing for same slope but different intercepts in the regression of weight against days was better than the full model testing for different slopes and intercepts. Similarly, mesh size did not affect the decomposition rate of Ulva sp. based on the repeated measures ANOVA (Table 3).

Table 2. Ulva sp. Analysis of covariance in weight loss pattern during decomposition under different invertebrate exclusion regimes and comparison of weight loss patterns between trials. Full models test for differences in slope and intercept terms, whereas reduced models test for differences in intercepts only. res. $=$ residual $,{ }^{* * *} \mathrm{p}<0.001,{ }^{* *} \mathrm{p}<0.01$

\begin{tabular}{|lcccc|}
\hline Model & res. df & RSS & SS & $F$ \\
\hline Mesh size = factor, days = covariate & & \\
Trial 1 & & & & \\
$\quad$ Full model & 30 & 0.125 & 0.008 & 0.93 \\
$\quad$ Reduced model & 32 & 0.132 & 0.061 & $7.30^{* *}$ \\
Trial 2 & & & & \\
$\quad$ Full model & 54 & 0.184 & 0.020 & 2.87 \\
Reduced model & 56 & 0.204 & 0.009 & 0.28 \\
& & & & \\
Trial = factor, days = covariate & & \\
$\begin{array}{l}5 \text { mm bags } \\
\text { Full model }\end{array}$ & 23 & 0.077 & 0.006 & 1.69 \\
$\quad$ Reduced model & 24 & 0.083 & 0.053 & $15.90^{* * *}$ \\
1 mm bags & & & & \\
$\quad$ Full model & 23 & 0.070 & 0.003 & 0.98 \\
Reduced model & 24 & 0.073 & 0.004 & 1.38 \\
$80 \mu m$ bags & & & & \\
$\quad$ Full model & 23 & 0.091 & 0.001 & 0.69 \\
Reduced model & 24 & 0.091 & 0.073 & $18.71^{* * *}$ \\
\hline
\end{tabular}

Table 3. Ulva sp. Repeated measures ANOVA for decomposition under different regimes of invertebrate exclusion during the 2 experiments ( $\mathrm{n}=4$ replicates/mesh size for Trial 1 and $n=5$ replicates/mesh size for Trial 2). Significant values are in bold

\begin{tabular}{|lcccc|}
\hline Source & df & MS & $F$ & $\mathrm{p}$ \\
\hline Trial 1 & & & & \\
Time & 3 & 7.67 & $\mathbf{3 . 7 8}$ & $\mathbf{0 . 0 3 3}$ \\
Mesh size & 2 & 12.86 & 2.81 & 0.107 \\
Time $\times$ Mesh size & 6 & 1.79 & 2.06 & 0.087 \\
Trial 2 & & & & \\
Time & 4 & 53.63 & $\mathbf{5 . 9 6}$ & $\mathbf{0 . 0 0 2}$ \\
Mesh size & 2 & 3.71 & 3.14 & 0.080 \\
Time $\times$ Mesh size & 8 & 1.47 & 2.10 & 0.054 \\
& & & & \\
\hline
\end{tabular}




\section{Supratidal invertebrates in Ulva sp. packs}

The invertebrate fauna in Ulva sp. packs included only a few species in each taxonomic group (Table 4). By far the most abundant taxon was the springtail Paraxenylla peruensis $\left(1165.9 \pm 309.3\right.$ ind. pack $\left.{ }^{-1}\right)$, followed by 3 species of mites $(82.9 \pm 17.0$ ind. pack ${ }^{-1}$, of which $21.4 \pm 5.8$ ind. pack ${ }^{-1}$ were from a species of Uropodidae) and the fly Thoracochaeta brachystoma $\left(23.6 \pm 4.8\right.$ adults pack $\left.^{-1}\right)$. In terms of biomass, the most important invertebrates in the bags were the talitrid amphipod, Transorchestia chiliensis, (42.8 mg pack ${ }^{-1}$ ), Paraxenylla peruensis $\left(2.8 \mathrm{mg} \mathrm{pack}^{-1}\right)$ and mites (1.3 mg pack $\left.{ }^{-1}\right)$.

Bags with mesh size of $80 \mu \mathrm{m}$ did not always exclude invertebrates larger than $80 \mu \mathrm{m}$ because one pack had 1383 mites and another pack contained 3445 springtails, despite the fact that bags appeared to be intact. However, in most $80 \mu \mathrm{m}$ bags, the total number of invertebrates was less than 150. Overall, the biomass of invertebrates in $80 \mu \mathrm{m}$ bags was significantly lower than the biomass of invertebrates in $1 \mathrm{~mm}$ and $5 \mathrm{~mm}$ samples (ANOVA, $F=46.48, \mathrm{p}<0.01$; Tukey's test, $\mathrm{p}<0.01)$.

\section{Successional change in supratidal invertebrate communities}

The number of invertebrates varied during the period of algal decomposition in $5 \mathrm{~mm}$ bags (Fig. 2). Log-transformed values for the total number of invertebrates for Trial 2 followed a polynomial curve where abundance $=(-0.010) \mathrm{d}^{2}+(0.181) \mathrm{d}+2.432$; the peak of this curve occurs for Day 9.335. In Trial 1, the number of invertebrates steadily increased between Day 1 and Day $9\left(F_{1,10}=6.16, p=0.03\right)$. Total invertebrate biomass for Ulva sp. packs in $5 \mathrm{~mm}$ bags did not vary during algal decomposition in both Trial $1\left(F_{1,10}=0.29, \mathrm{p}=\right.$ $0.60)$ and Trial $2\left(F_{1,16}=3.408, \mathrm{p}=0.083\right)$.

In Ulva sp. packs that excluded large invertebrates (1 mm bags), the number of invertebrates did not vary during Trial $1\left(F_{1,10}=2.25, \mathrm{p}=0.16\right)$ and Trial $2\left(F_{1,18}=\right.$ $0.03, p=0.86$ ). Similarly, biomass did not vary during algal decomposition in either Trial $1\left(F_{1,10}=2.21, \mathrm{p}=0.17\right)$ or $2\left(F_{1,18}=0.06, p=0.80\right)$. The number of invertebrates in Ulva sp. packs did not differ between 5 and $1 \mathrm{~mm}$ bags for either trial (2-way ANOVAs: $F_{1,18}=0.18, \mathrm{p}=0.68$ for Trial 1 and $F_{1,32}=0.74, \mathrm{p}=0.40$ for Trial 2).

The abundance and biomass of the most conspicuous groups varied through time in $5 \mathrm{~mm}$ bags during Trial 2 (Fig. 3). Numbers (although not biomass values) followed a polynomial curve for Paraxenylla peruensis (abundance $=[-0.014] \mathrm{d}^{2}+[0.288] \mathrm{d}+1.827$, peak at Day 10.148) and for mites (abundance $=[-0.008] \mathrm{d}^{2}+$ $[0.114] d+1.626$, peak at Day 4.021). The number and biomass of Transorchestia chiliensis $\left(F_{1,15}=7.17, \mathrm{p}=\right.$ 0.017 for abundance; $F_{1,15}=7.73, \mathrm{p}=0.01$ for biomass) and Thoracochaeta brachystoma $\left(F_{1,16}=19.64, \mathrm{p}<0.01\right.$ for abundance; $F_{1,16}=17.41, \mathrm{p}<0.01$ for biomass) steadily decreased with time. At the same time, there was an increase in the number of pupae of $T$. brachystoma $\left(F_{1,16}=8.07, \mathrm{p}=0.01\right)$, but no variation in the number of larval forms $\left(F_{1,16}=0.11, \mathrm{p}=0.74\right)$. The number and biomass of the 2 species of rove beetles Cafius sp. and Carpelimus sp. did not vary during algal decomposition $\left(F_{1,16}=1.86, \mathrm{p}=0.19\right.$ for abundance; $F_{1,16}=0.38, \mathrm{p}=0.54$ for biomass).

\section{Food web of arthropods in decomposing Ulva sp.}

Stable isotope analyses (Fig. 4) suggested that Ulva sp. was an important source of carbon for arthropods in litterbags because the average $\delta^{13} \mathrm{C}$ values of most arthropods were not significantly different from those 

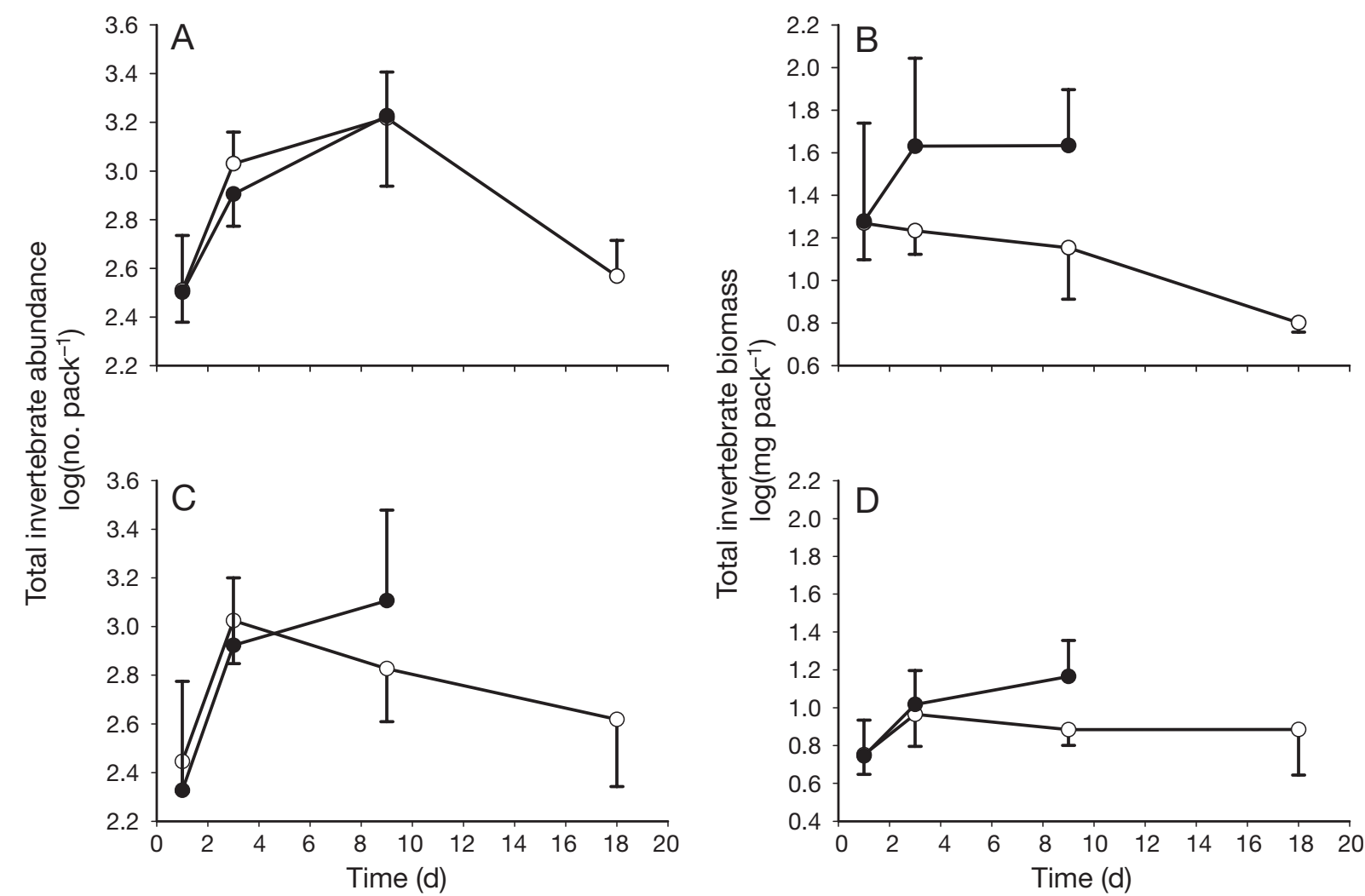

Fig. 2. Ulva sp. (A) Number and (B) biomass of invertebrates (no invertebrates excluded) decomposing in $5 \mathrm{~mm}$ bags during Trial 1 (-) (8 May to 16 May 2003) and Trial 2 (O) (22 May to 8 June 2003). (C) Number and (D) biomass of invertebrates (excluding invertebrates larger than $1 \mathrm{~mm}$ ) decomposing in $1 \mathrm{~mm}$ bags during Trial $1(\mathbf{O})$, and Trial $2(\mathrm{O})$. Error bars indicate SE calculated from 4 (Trial 1) and 5 (Trial 2) replicate bags

of Ulva sp. (Table 5). Carbon isotopic values of the centipede Thindyla litoralis and the rove beetle Carpelimus sp. were significantly different from those of Ulva sp. only when we assumed that centipedes and the rove beetle Carpelimus sp. occupied the second and third trophic levels. Estimates of trophic position based on $\delta^{15} \mathrm{~N}$ values did not fully support these assumptions for Carpelimus sp., but supported the idea that centipedes were obtaining carbon from sources other than Ulva sp. (see next paragraph).

Arthropod consumers in decomposing Ulva sp. occupied 3 trophic levels above Ulva sp. (Table 6). A first group of consumers, with estimated trophic positions ranging from 1.39 to 1.53, included the beach flea Transorchestia chiliensis and the rove beetle Carpelimus sp., which probably feed exclusively upon Ulva sp. or epiphytic primary producers (e.g. diatoms). The second group included the largest number of consumers, ranging from predators (e.g. the solifuge Chinchippus peruvianus) to consumers that probably had a mixed diet (e.g. the springtail Paraxenylla peruensis and the fly Thoracochaeta brachystoma). The 'top' predators (trophic position between 2.53 and 2.62) in decomposing Ulva sp. were mites and centipedes.

\section{DISCUSSION}

The mass loss was extremely rapid for decomposing Ulva sp. in Paracas Bay and ranged at the higher end of reported values for beach-cast material decomposition. Green algae differ in physical and chemical properties from other algal and plant wrack deposited on beaches. Green algae should decompose faster than other algae under similar environmental conditions because they have reduced structural defenses (Padilla 1989, Duffy \& Hay 1990), reduced antibiotic activity (Magallanes et al. 2003) and lower concentrations of phenolic and secondary compounds (Faulkner 1993, Targett \& Arnold 1998) than kelp, rhodophytes and seagrass. This hypothesis is supported by typically slower breakdown rates in seagrass versus macroalgae (Ochieng \& Erftemeijer 1999, Fourqurean \& Schrlau 2003), but data comparing breakdown rates among different types of seaweeds are rare in the literature. Our measured decomposition rates are similar to values reported by Inglis (1989) for the kelp Macrocystis pyrifera along a New Zealand sandy beach.

Smith \& Foreman (1984) compared the breakdown rate of submerged sample bags for 10 species of sea- 


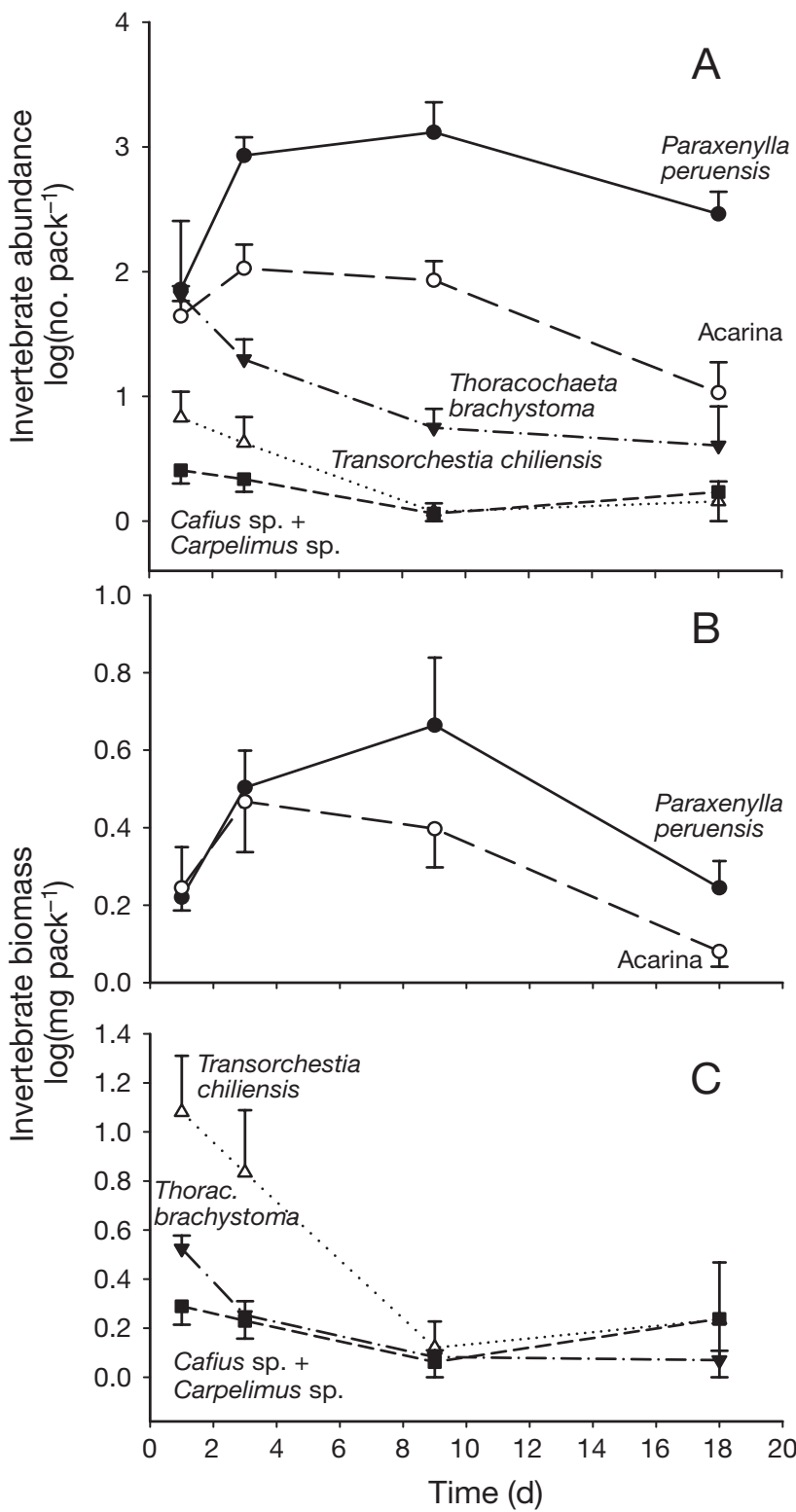

Fig. 3. Ulva sp. (A) Number (log-transformed data) of Paraxenylla peruensis, $(\mathrm{O})$ Acarina (unidentified species), $(\boldsymbol{\nabla})$ Thoracochaeta brachystoma, $(\Delta)$ Transorchestia chiliensis and ( $\square$ ) rove beetles (one species of Cafius sp. and one species of Carpelimus sp.) found in Ulva sp. decomposing in $5 \mathrm{~mm}$ bags during Trial 2. (B) Biomass (log-transformed data) of (0) P. peruensis and $(\mathrm{O})$ Acarina. $(\mathrm{C})$ Biomass of $(\Delta)$ Transorchestia chiliensis, $(\boldsymbol{\nabla}) T$. brachystoma and $(\boldsymbol{\square})$ rove beetles. Error bars indicate SE calculated for 5 replicate bags

weeds in the Strait of Georgia, Canada, and found that species with lower crude fiber content and decreasing particle size decomposed faster than other species. We do not have data on fiber content of Ulva sp. in Paracas Bay, but comparative studies at other locations showed similar or higher amounts of both crude and dietary fiber content in Ulva species with respect to other

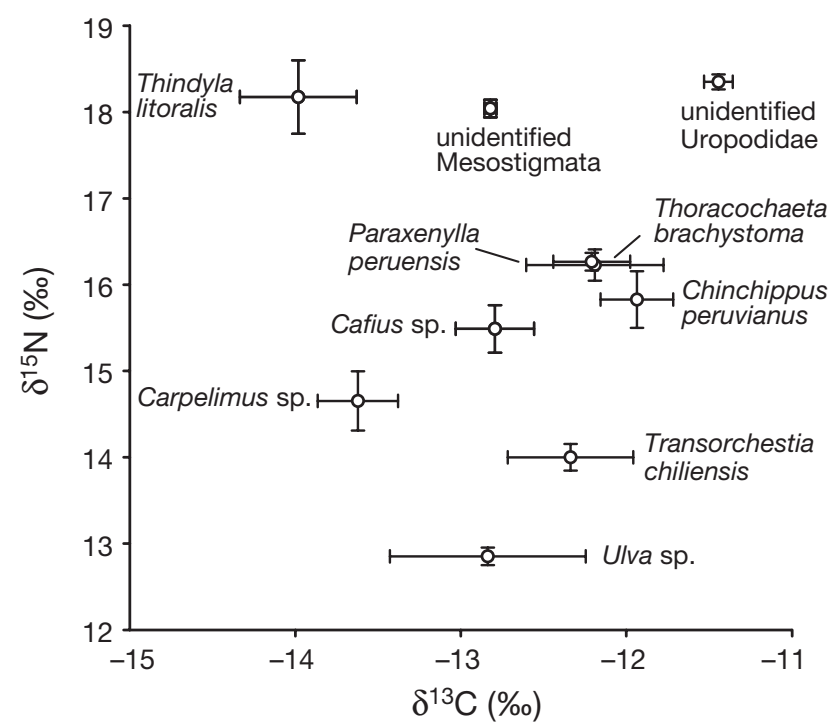

Fig. 4. Ulva sp. Average (mean $\pm \mathrm{SE}, \mathrm{n}=5$ replicates) $\delta^{13} \mathrm{C}$ and $\delta^{15} \mathrm{~N}$ values of the most important (by biomass) macro- and mesoinvertebrates found during the decomposition of beachcast Ulva sp. The centipede Thindyla litoralis and the solifuge Chinchippus peruvianus are terrestrial predators that feed on supratidal invertebrates at the study site. See 'Materials and methods' for details on sampling and stable isotope analyses

green algae, kelp and rhodophytes (Ledesma et al. 1999, Carrillo et al. 2002). Invertebrate shredders could increase the seaweed decomposition rate by reducing the size of particles. A greater surface (relative to volume) in smaller particulate material exposed to microbial attack may explain the effect of particle size on decomposition rate (Colombini \& Chelazzi 2003).

The decomposition of beach-cast green macroalgae has received relatively little attention, especially when compared with studies that considered stranded kelp. This is unfortunate because species of Ulva are characterized by a high growth rate and often dominate in eutrophic coastal waters (Viaroli et al. 2005), a condition that is becoming increasingly common (Morand \& Briand 1996). A better understanding of processes controlling the decomposition of beach-cast Ulva sp. could prove useful in mitigating the effects of algal blooms upon intertidal and supratidal communities.

\section{Role of and variation in supratidal invertebrate communities}

Decaying Ulva sp. was quickly colonized by macroand mesoinvertebrates. These groups were exclusively supra- and intertidal based upon our collections along a gradient from the intertidal to the supratidal and desert habitats (A. Catenazzi pers. obs.). A few desert arthropods were also found in the litterbags, such as 
Table 5. Ulva sp. Results of Student's $t$-tests between $\delta^{13} \mathrm{C}$ of Ulva sp. and $\delta^{13} \mathrm{C}$ of invertebrates in packs for different trophic fractionations and assuming an average value of $0.39 \%$ for each trophic level. Tests were not computed if feeding patterns of a species do not support assumptions of a given trophic fractionation factor (e.g. Thindyla litoralis is predaceous and will not feed directly on Ulva sp.). Significant $t$ and $\mathrm{p}$ values are in bold

\begin{tabular}{|c|c|c|c|c|c|c|}
\hline \multirow[t]{3}{*}{ Consumer } & \multicolumn{6}{|c|}{$\delta^{13} \mathrm{C}$ trophic fractionation } \\
\hline & \multicolumn{2}{|c|}{$+0.39 \%$} & \multicolumn{2}{|c|}{$+0.78 \%$} & \multicolumn{2}{|c|}{$+1.17 \%$} \\
\hline & $t$ & $\mathrm{p}$ & $t$ & $\mathrm{p}$ & $t$ & $\mathrm{p}$ \\
\hline Transorchestia chiliensis & 0.50 & 0.63 & - & - & - & - \\
\hline Carpelimus sp. & 1.84 & 0.10 & 2.44 & 0.04 & 3.05 & 0.02 \\
\hline Cafius sp. & 0.54 & 0.60 & 1.15 & 0.28 & 1.77 & 0.11 \\
\hline Chinchippus peruvianus & - & - & -0.19 & 0.85 & 0.42 & 0.68 \\
\hline Paraxenylla peruensis & -0.36 & 0.73 & 0.18 & 0.86 & 0.72 & 0.49 \\
\hline Thoracochaeta brachystoma & -0.37 & 0.72 & 0.24 & 0.82 & 0.85 & 0.42 \\
\hline Thindyla litoralis & - & - & 2.75 & 0.03 & 3.31 & 0.01 \\
\hline Unidentified Mesostigmata & 0.63 & 0.55 & 1.29 & 0.23 & 1.94 & 0.09 \\
\hline Uropodid mite & -1.68 & 0.13 & -1.03 & 0.33 & -0.37 & 0.72 \\
\hline
\end{tabular}

Table 6. Estimated trophic position of intertidal invertebrates, assuming that Ulva sp. is the primary producer and that the trophic fractionation factor $\Delta=3.4 \%$

\begin{tabular}{|lcc|}
\hline Producer or consumer & Trophic position & SE \\
\hline Ulva sp. & 1.00 & - \\
Transorchestia chiliensis & 1.39 & 0.07 \\
Carpelimus sp. & 1.53 & 0.10 \\
Cafius sp. & 1.78 & 0.08 \\
Chinchippus peruvianus & 1.88 & 0.10 \\
Paraxenylla peruensis & 1.99 & 0.05 \\
Thoracochaeta brachystoma & 2.01 & 0.03 \\
Thindyla litoralis & 2.56 & 0.13 \\
Unidentified Mesostigmata & 2.53 & 0.03 \\
Uropodid mite & 2.62 & 0.03 \\
\hline
\end{tabular}

the tenebrionid beetle Cordibates fuscus and a species of ant, Solenopsis sp. Macroinvertebrate abundance and biomass steadily declined in the period following colonization, similar to the situation observed by Inglis (1989) in decomposing kelp. The decrease in biomass was caused mainly by the decrease in the amphipod Transorchestia chiliensis, confirming a well-known pattern of amphipods as early colonizers of newly deposited beach-cast macroalgae (Griffiths \& StentonDozey 1981, Colombini et al. 2000). Another pattern characteristic of beach invertebrate succession was observed in the reproductive cycle of flies, with adult Thoracochaeta brachystoma arriving early to lay eggs, a decreasing number of adults from Day 1 to Day 18, and a concomitant increase in the number of pupae. This cycle allows flies to reproduce before the arrival of the next spring tide (Dobson 1974).

Temporal variations in the invertebrate community may have been caused by changes in the nutritional quality of the algae, loss of moisture, greater exposure to predators, or by the movement of consumers in and out of the litter bags. The movement of consumers is a likely source of variation in this system because beach organisms are known to adjust their movement patterns with daily variations in the tidal cycle (Jaramillo et al. 2000, but see Defeo \& McLachlan 2005 for the relative independence of supratidal organisms to swash regimes in sandy beaches). The supratidal mesofauna of Paracas Bay differed from other studies because it was dominated by a springtail and because other groups, such as nematodes and oligochaetes, common in other locations (Inglis 1989, Ochieng \& Erftemeijer 1999, Jedrzejczak 2002) were numerically negligible in our study system. The shelly substrate at our study beach provides suitable retreats for amphipods and springtails, but little sand for burrowing taxa such as enchytraeid oligochaetes.

The role of supratidal invertebrates in the decomposition of Ulva sp. seemed to be marginal according to the results of our experiment. Hieber \& Gessner (2002) listed several caveats associated with the use of litter bags in estimating the effects of consumers on decomposition rates. However, Inglis (1989) did not detect any difference when testing for the effects of mesh size alone (without macro- and mesofauna) on the decomposition rate of seaweeds in the laboratory. Some of the alternatives proposed by Hieber \& Gessner (2002) to litter bag experiments were to estimate feeding activity of consumers based on consumption rates measured in feeding trials in the laboratory. Zimmer et al. (2002) measured promotion of microbial respiration and amount of litter processed by supralittoral isopods and found that differences in isopod performance and contribution to litter breakdown were linked to changes in the chemical composition of the litter and speciesspecific differences in digestive capabilities and rates of net litter processing. In our study we decided to identify consumers that fed directly on Ulva sp. by using stable isotope analyses (see next section); the relative impact of these consumers on Ulva sp. material could be estimated by assuming feeding and growth rates for each invertebrate.

\section{Food web in decomposing Ulva sp. and contribution to terrestrial consumers}

The main source of energy for the consumers in litterbags was Ulva sp.. The slight shift of $\delta^{13} \mathrm{C}$ of con- 
sumers to the right of the value for Ulva sp. (Fig. 4) coincides with the expected variation, assuming a trophic fractionation of approximately $0.39 \%$ at each trophic interaction. However, we cannot exclude epiphytic diatoms with $\delta^{13} \mathrm{C}$ similar to those of Ulva sp. as potential sources of energy to consumers because we did not collect and isolate these producers for stable isotope analysis. In the analysis of $\delta^{15} \mathrm{~N}$, estimates of trophic position agree well with what is known about the diet of consumers: talitrid amphipods, for example, occupy low trophic levels (Adin \& Riera 2003), whereas predatory invertebrates, such as centipedes and solifuges, are near the top of the food web. One of the surprising findings was that springtails had a higher trophic position than solifuges. Consumption of heterotrophic microorganisms such as fungi and bacteria may explain the elevated $\delta^{15} \mathrm{~N}$ in springtails. The elevated trophic positions estimated for mites indicated that these were mainly predaceous and/or scavenging taxa. While sorting invertebrates in the laboratory, we often found hundreds of mites attached to carcasses of centipedes, suggesting that mites were feeding upon other predators.

Invertebrates associated with decomposing Ulva sp. in Paracas Bay are a significant source of food for terrestrial predators. These predators include sandpipers and other wading birds feeding on amphipods, flies and rove beetles (Duffy et al. 1981), lizards (Catenazzi et al. 2005), solifuges, geckos and scorpions (Catenazzi \& Donnelly 2007), ghost crabs Ocypode gaudichaudii, spiders and predaceous beetles (A. Catenazzi pers. obs.). For desert consumers such as arachnids and lizards, the proportion of energy and nutrients derived from invertebrates associated with decomposing Ulva sp. exceeds the proportion obtained from other sources, with important consequences on the abundance and distribution of these predators (Catenazzi \& Donnelly 2007). The dependence of predators on supratidal consumers is especially significant in Paracas Bay and much of the coastal desert of central and southern Peru because the extremely low levels of terrestrial primary productivity alone cannot support large populations of terrestrial consumers. Decomposition of Ulva sp. in Paracas Bay is one of the most important processes that make marine-derived resources available to terrestrial consumers.

Acknowledgements. We thank J. Carrillo for invaluable field and laboratory assistance, the Reserva Nacional de Paracas for logistic support, the National Institute of Natural Resources for issuing research and collecting permits, M. Kershaw for isotopic ratio measurements, P. Camus, J. Fourqurean, A. McLachlan, 5 anonymous reviewers and the FIU Herpetology Club for comments on the manuscript, and J. Chapman, J. Ferrer, L. H. Herman, A. Minelli and J. G. Palacios-Vargas for species identifications. A.C. was funded by a Florida International University Dissertation Year Fellowship and by grants from the Organization for Tropical Studies, the PADI Foundation and the American Museum of Natural History. This is publication number 127 of the Tropical Biology Program at Florida International University.

\section{LITERATURE CITED}

Adin R, Riera P (2003) Preferential food source utilization among stranded macroalgae by Talitrus saltator (Amphipod, Talitridae): a stable isotopes study in the northern coast of Brittany (France). Estuar Coast Shelf Sci 56:91-98

Bedford AP, Moore PG (1984) Macrofaunal involvement in the sublittoral decay of kelp debris. The detritivore community and species interactions. Estuar Coast Shelf Sci 18: 91-111

Bolam SG, Fernandes TF, Read P, Raffaelli D (2000) Effects of macroalgal mats on intertidal sandflats: an experimental study. J Exp Mar Biol Ecol 249:123-137

Bustamante RH, Branch GM (1996) The dependence of intertidal consumers on kelp-derived organic matter on the west coast of South Africa. J Exp Mar Biol Ecol 196:1-28

Carrillo S, Valdes M, Ramos F, Pérez-Gil F, Sánchez I (2002) Algas marinas de Baja California Sur, México: valor nutrimental. Arch Latinoam Nutr 52:400-405

Catenazzi A, Donnelly MA (2007) The Ulva sp. connection: Marine green algae subsidize terrestrial consumers in coastal Peru. Oikos 116:75-86

Catenazzi A, Carrillo J, Donnelly MA (2005) Seasonal and geographic eurythermy in a coastal Peruvian lizard. Copeia 2005:713-723

Chapin FS, Matson PA, Mooney HA (2002) Principles of terrestrial ecosystem ecology. Springer, New York

Colombini I, Chelazzi L (2003) Influence of marine allochthonous input on sandy beach communities. Oceanogr Mar Biol Annu Rev 41:115-159

Colombini I, Aloia A, Fallaci M, Pezzoli G, Chelazzi L (2000) Temporal and spatial use of stranded wrack by the macrofauna of a tropical sandy beach. Mar Biol 136:531-541

Defeo O, McLachlan A (2005) Patterns, processes and regulatory mechanisms in sandy beach macrofauna: a multiscale analysis. Mar Ecol Prog Ser 295:1-20

Dobson T (1974) Mechanisms controlling species composition in natural populations of the seaweed fly Coelopa. J Nat Hist 8:653-673

Duffy JE, Hay ME (1990) Seaweed adaptations to herbivory. Bioscience 40:368-375

Duffy DC, Atkins N, Schneider DC (1981) Do shorebirds compete on their wintering grounds? Auk 98:215-229

Faulkner DJ (1993) Marine natural products. Nat Prod Rep 10: 497-539

Fourqurean J, Schrlau J (2003) Changes in nutrient content and stable isotpe of $\mathrm{C}$ and $\mathrm{N}$ during decomposition of seagress and mangrove leaves along a nutrient availability gradient in Florida Bay, USA. Chem Ecol 19:373-390

Griffiths CL, Stenton-Dozey JME (1981) The fauna and the rate of degradation of stranded kelp. Estuar Coast Shelf Sci 12:645-653

Griffiths CL, Stenton-Dozey JME, Koop K (1983) Kelp wrack and the flow of energy through a sandy beach ecosystem. In: McLachlan A, Erasmus $\mathrm{T}$ (eds) Sandy beaches as ecosystems. W. Junk, The Hague, p 547-556

Hieber M, Gessner MO (2002) Contribution of stream detritivores, fungi and bacteria to leaf breakdown based on biomass estimates. Ecology 83:1026-1038

Inglis G (1989) The colonisation and degradation of stranded 
Macrocystis pyrifera (L.) C. Ag. by the macrofauna of a New Zealand sandy beach. J Exp Mar Biol Ecol 125: 203-217

Jaramillo E, Avellanal MH, González M, Kennedy F (2000) Locomotor activity of Phalerisida maculata Kulzer (Coleoptera, Tenebrionidae) on Chilean sandy beaches. Rev Chil Hist Nat 73:67-77

Jedrzejczak MF (2002) Stranded Zostera marina L. vs. wrack fauna community intreactions on a Baltic sandy beach (Hel, Poland): a short-term pilot study. Part II. Driftline effects of successional changes and colonisation of beach fauna. Oceanologia 44:367-387

Koepcke HW, Koepcke M (1952) Sobre el proceso de transformación de la materia orgánica en las playas arenosas marinas del Perú. Publ Mus Hist Nat 'Javier Prado' Ser A (Zool) 8:1-24

Koop K, Lucas MI (1983) Carbon flow and nutrient regeneration from the decomposition of macrophyte debris in a sandy beach microcosm. In: McLachlan A, Erasmus T (eds) Sandy beaches as ecosystems. W. Junk, The Hague, p 249-262

Ledesma L, Gregorio R, Valdes O, Gonzalez N, Varona N, Abreu M (1999) Algunas características nutricionales de la macroalga Ulva sp. de la plataforma insular cubana. Alimentaria 304:51-54

Magallanes C, Córdova C, Orozco R (2003) Actividad antibacteriana de extractos etanólicos de macroalgas marinas de

Editorial responsibility: Otto Kinne (Editor-in-Chief), Oldendorf/Luhe, Germany la costa central del Perú. Rev Peru Biol 10:125-132

Morand P, Briand X (1996) Excessive growth of macroalgae: a symptom of environmental disturbance. Bot Mar 39: 491-516

Ochieng CA, Erftemeijer PLA (1999) Accumulation of seagrass beach cast along the Kenyan coast: a quantitative assessment. Aquat Bot 65:221-238

Padilla DK (1989) Algal structural defenses: form and calcification in resistance to tropical limpets. Ecology 70: $835-842$

Post DM (2002) Using stable isotopes to estimate trophic position: models, methods, and assumptions. Ecology 83: 703-718

Smith BD, Foreman RE (1984) An assessment of seaweed decomposition within a southern Strait of Georgia seaweed community. Mar Biol 84:197-205

Targett NM, Arnold TM (1998) Predicting the effects of brown algal phlorotannins on marine herbivores in tropical and temperate oceans. J Phycol 34:195-205

Viaroli P, Bartoli M, Azzoni R, Giordani G, Mucchino C, Naldi M, Nizzoli D, Taje L (2005) Nutrient and iron limitation to Ulva sp. blooms in a eutrophic coastal lagoon (Sacca di Goro, Italy). Hydrobiologia 550:57-71

Zimmer M, Pennings SC, Buck TL, Carefoot TH (2002) Species-specific patterns of litter processing by terrestrial isopods (Isopoda: Oniscidea) in high intertidal salt marshes and coastal forests. Funct Ecol 16:596-607

Submitted: October 19, 2006; Accepted: June 11, 2007 Proofs received from author(s): October 29, 2007 